\title{
PETROLEUM SULFONATES PREPARATION AND EVALUATION FOR CHEMICAL ENHANCED OIL RECOVERY IN COLOMBIAN OIL FIELDS
}

\author{
PREPARACIÓN DE SULFONATOS DE PETRÓLEO Y EVALUACIÓN PARA RECOBRO \\ QUÍMICO MEJORADO EN CAMPOS DE PETRÓLEO COLOMBIANOS
}

Zarith del Pilar Pachón-Contreras ${ }^{1 *}$, Fernando-Andrés Rojas-Ruíz ${ }^{2}$, Miguel-José Rondón-Antón², Juliana-Carolina Vidal-Prada ${ }^{2}$ and Freddy-Alexander Pulido-Solano ${ }^{2}$

\author{
'Ecopetrol S.A. - Instituto Colombiano del Petróleo (ICP), A.A. 4185 Piedecuesta, Santander, Colombia \\ 2UT Pexlab, Bucaramanga, Santander, Colombia \\ e-mail: zarith.pachon@ecopetrol.com.co
}

(Received: Aug. 22, 2013; Accepted: Oct. 29, 2014)

\begin{abstract}
A n efficient method for preparing petroleum sulfonates is described in this article. Petroleum sulfonates were prepared from five different refinery cuts and characterized by infrarred and ultra-violet spectroscopy. Their hydrophilic-lipophilic relative afinity was assessed by performing phase behavior scans. The prepared surfactants were evaluated in formulations for Chemical Enhanced Oil Recovery (CEOR), showing that, under the evaluation conditions, the solubilization ratios increase with the structural similarity between the crude oil and the surfactant molecules. It was confirmed that, when used as secondary surfactants, the petroleum sulfonates here prepared allow to achieve relatively high solubilization parameters.
\end{abstract}

Keywords: Surfactants, Sulfonation, Chemical synthesis, Sulfonation reaction, Enhanced oil recovery, Characterization, Infrared spectroscopy, UV spectroscopy.

How to cite: Pachón-Contreras, Z., Rojas-Ruíz, F. A., Rondón-Antón, M., Vidal-Prada, J. C. \& Pulido-Solano, F. A. (2014). Petroleum sulfonates preparation and evaluation for chemical enhanced oil recovery in Colombian oil fields. CT\&F - Ciencia, Tecnología y Futuro, 5(5), 55-73.

*To whom correspondence should be addressed 


\section{RESUMEN}

n el presente trabajo se decribe un método eficiente para la preparación de sulfonatos de petróleo.

Los sulfonatos de petróleo se prepararon a partir de cinco cortes de refinería diferentes y se caracterizaron por espectroscopía de infrarrojo y ultravioleta. Su afinidad relativa hidrófilica lipófilica se evaluó mediante la realización de comportamientos de fase. Los tensoactivos preparados se evaluaron en formulaciones para Recobro Químico Mejorado demostrando que, bajo las condiciones de evaluación, las relaciones de solubilización aumentan con la similitud estructural que existe entre el petróleo crudo y las moléculas del surfactante utilizado. Se confirma que, cuando se utilizan como surfactantes secundarios, los sulfonatos de petróleo aquí preparados permiten alcanzar parámetros de solubilización relativamente elevados.

Palabras clave: Surfactantes, Sulfonación, Síntesis química, Reacción de sulfonación, Recobro mejorado de petróleo, Caracterización, Espectroscopia infrarroja, Espectroscopia de luz ultravioleta.

\section{RESUMO}

Nosen

o presente trabalho é descrito um método eficiente para a preparação de sulfonatos de petróleo. Os sulfonatos de petróleo são preparados a partir de cinco cortes de refinaria diferentes e são caracterizados por espectroscopia de infravermelho e ultravioleta. Sua afinidade relativa hidrófilica lipófilica foi avaliada mediante a realização de comportamentos de fase. Os tensoativos preparados foram avaliados em formulações para Recuperação Química Melhorada demonstrando que, sob as condições de avaliação, as relações de solubilização aumentam com a semelhança estrutural que existe entre o petróleo cru e as moléculas do surfactante utilizado. Confirma-se que, quando são utilizados como surfactantes secundários, os sulfonatos de petróleo aqui preparados permitem atingir parâmetros de solubilização relativamente elevados.

Palavras-chave: Surfactante, Sulfonação, Síntese química, Reação de sulfonação, Recuperação melhorada de petróleo, Caracterização, Espectropia de infravermelho, Espectropia de luz ultravioleta. 


\section{INTRODUCTION}

Petroleum industry has to deal with the fact that only a reduced portion ( $20 \%$ to $40 \%)$ of the petroleum originally present in a reservior can be extracted by conventional mechanisms. However, it is possible to obtain higher recovery factors by applying advanced techniques. Among them, there is a method in which chemical formulations containing surfactants are injected through the formation (Jamaloei, 2009; Iglauer et al., 2010; Babadagli, Al-Bemani, Boukadi \& Al Maamari, 2005; Babadagli \& Boluk, 2005; El-Batanoney, AbdelMoghny \& Ramzi, 1999; Levitt et al., 2009). This method is called Chemical Enhanced Oil Recovery (CEOR) (Sheng, 2011). Surfactants enhances oil recovery by reducing capillary forces that traps the oil in the porous media (Melrose \& Brandner, 1974). These capillary forces are directly correlated with the interfacial tension between water and oil (Taber, 1969). In order to maximize oil recovery, the interfacial tension has to descend down to ultra low values. This condition can be obtained at the so called optimum formulation where the surfactant affinity becomes equal for both phases (Salager, 1977; Thanaa, 2006).

Among different surfactant types, petroleum sulfonates outstand in the application on CEOR processes for economical and practical reasons (Salager, Anton \& Aubry, 2006; Almalik, Attia \& Jang, 1997; Liu, Dong, Yue \& Hou, 2006). Different studies have been reported on petroleum sulfonates synthetized from crude-oil and from vacuum distillation fractions (Salager et al., 2006; Basu \& Shravan, 2008; Djedri et al., 2010). Due to its sulfonation susceptibility, refinery cuts are considered a very good source of raw materials for the petroleum sulfonates synthesis (Djedri et al., 2010; Sandvik, Gale \& Denekas, 1977; Harban \& Johnson, 1963). In the last 3 decades, advances on organic chemistry have allowed to produce more specific molecules with improved performance and resistance to harsh conditions like high temperature, high salinity and hardness of the water.

In this work, different petroleum sulfonates are prepared and their spectral characterization is reported. Under the evaluation conditions, it was verified that the solubilization parameters for two crude oils tested showed to augment as the structural likeness between the crude oil molecules and the lipophilic ends of the sulfonates increased. The petroleum sulfonates here prepared, when used as secondary surfactants, allowed to achieve relatively high solubilization parameters values.

\section{STATE OF THE ART}

Producing ultra-low interfacial tension is one of the most important mechanisms for oil recovery with respect to surfactant flooding. Therefore, in order to efficiently displace crude oil trapped in the pores of reservoir rock, it is necessary to reduce the interfacial tension between the oil and a surfactant aqueous phase down to ultra-low values. Winsor (1954) found that the phase behavior in water/surfactant/oil systems depends on the interactions between the surfactant molecules and the molecules of water and oil, and introduced the relation $\mathrm{R}$ that involves the energetic contributions of these interactions.

Throughout a formulation screening, it is possible to study the influence over a system caused by the equilibrium properties, particularly the adsorption at the interphase, the composition of the present phases and the interfacial and/or surface tension, among others (Salager, 1977; Bourrel, Graciaa, Schechter \& Wade, 1979). The one-dimension screening method allows modifying the formulation of a water-surfactant-oil system in a controlled way, by preparing a series of test tubes where the water/oil ratio is constant, while one of the screening variables is gradually modified. This method allows to analyze the phase behavior (Winsor types transitions) and the variations on the system properties.

When a formulation screening is performed, the interfacial tension can achieve a minimum value under a specific value of the chosen screening parameter (Salager et al., 2006). According to the obtained results, it has been possible to establish numeric equivalencies between these variables for different kinds of surfactants, oils and aqueous phases (Salager, 1977).

A property of interest for the surfactant or a mixture of these products characterization is their lipophilic hydrophilic tendency, which can be expressed through different concepts like the Hydrophilic Lipophilic Deviation (HLD), among others. The HLD was described by Salager et al. (2006), as a dimensionless numeric expression of the known Surfactant Affinity Difference 
(SAD). The HLD is related to the surfactant partitioning coefficient and can be expressed as a lineal relation that includes all the formulation variables. In the simplified case where the aqueous phase is a sodium chloride solution, and the oil phase is an n-alkane, the HLD is expressed according to the surfactant being an ionic or non-ionic molecule. For anionic surfactants, the HLD is expressed by the Equation 1 (Witthayapanyanon, Harwell \& Sabatini, 2008; Salager et al., 2006).

$\mathrm{HLD}=\sigma+\ln \mathrm{S}-\mathrm{kEACN}+\mathrm{t} \Delta \mathrm{T}+\mathrm{aA}$

The $\sigma$ parameter is a characteristic value of a surfactant that is present in a specific system composed by a water phase, brine, oil and alcohol. In general terms, highly lipophilic surfactants present large sigma values. On the other hand, the more hydrophilic the surfactant is, the lower its sigma will be, even reaching negative values (Salager et al., 2006).

The formation of a microemulsion requires a certain hydrophilic lipophilic balance, which means that the interactions of the surfactant with the water and the oil phase molecules become equal. This condition can be fulfilled when the phase equilibrium has Winsor III behavior and the formulation is optimum $(\mathrm{HLD}=0)$. This is a physicochemical environment in which the surfactant affinity for the aqueous phase equals its affinity for the oil phase. The optimum state corresponds to equal volumes of water and oil solubilized in the microemulsion phase (Nazar, Shah \& Khosa, 2011). These volumes depend on the class and quantity of surfactant present in the system, and can be compared defining the Solubilization Parameters (SP) with respect to water and oil $\left(S P_{W}\right.$ and $S P_{O}$ respectively) (See Equation 2) (Witthayapanyanon et al., 2008; Salager et al., 2006).

$\mathrm{SP}_{\mathrm{w}}=\frac{V_{w}}{V_{s}} \quad \mathrm{SP}_{\mathrm{o}}=\frac{V_{o}}{V_{s}}$

Where, $V_{W}$ and $V_{O}$ are the volumes of water and oil solubilized, and $V_{S}$ is the volume or surfactant in the microemulsion (middle) phase. When $S P_{w}$ equals $S P_{o}$, the interfacial tension reaches a minimum value and the corresponding value is called the Solubilization Ratio (SR) at the optimum. According to Huh, the SR is stretchy related to the interfacial tension at the optimum (Huh, 1979). And it is practical when not counting with a spinning drop interfacial tension meter.

In this paper, the preparation of petroleum sulfonates from selected petroleum distillate fractions from Colombian refineries -based on the presence of sulfonable compounds- is reported, and their potential employment in CEOR projects on Colombian oilfields was assessed.

\section{EXPERIMENTAL DEVELOPMENT}

\section{Materials}

The refinery cuts employed for the preparation of petroleum sulfonates were obtained from Ecopetrol S.A. Table 1 shows some of their physical and chemical properties.

Crude oils used on phase behavior studies were samples from Colombian oil fields Yariguí and Lisama. Table 2 presents the SARA analysis (Meléndez et al., 2012), API gravity and kinematic viscosity for the employed oils.

Other reagents were purchased from Sigma and Aldrich Chemical Co. and used without further treatment.

\section{Preparation of Petroleum Sulfonates}

Sulfonation reactions were conducted according to literature procedures (Basu \& Shravan, 2008; Djedri et al., 2010). Figure 1 schematizes a general chemical reaction that takes place in the sulfonation process.

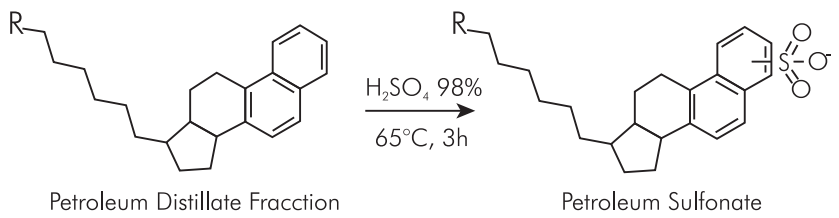

Figure 1. General chemical reaction taking place in the preparation of petroleum sulfonates. The chemical structures for the petroleum distillate and for the sulfonate produced are hypothetical molecules suggested according to different literature reports. 
Table 1. Characteristics of petroleum fractions used on sulfonates preparation.

\begin{tabular}{|c|c|c|c|c|c|}
\hline Parameter & $\begin{array}{l}\text { Light Naphtenic } \\
\text { Base (BN-100H) }\end{array}$ & $\begin{array}{l}\text { Light Vacuum } \\
\text { Gasoil (LVGO) }\end{array}$ & $\begin{array}{l}\text { High Vacuum } \\
\text { Gasoil (HVGO) }\end{array}$ & $\begin{array}{l}\text { Light Cycle Oil } \\
\text { (LCO) }\end{array}$ & $\begin{array}{c}\text { Demetalized Oil } \\
\text { (DMO) }\end{array}$ \\
\hline & $\begin{array}{c}\text { Product of the } \\
\text { combined } \\
\text { distillation of } \\
\text { naphthenic crudes. } \\
\text { Composed } \\
\text { primarily of } \\
\text { aromatic and } \\
\text { aliphatic } \\
\text { hydrocarbons from } \\
C_{5} \text { to } C_{12} \text {. }\end{array}$ & $\begin{array}{l}\text { Complex mixture } \\
\text { of hydrocarbons } \\
\text { obtained by vacuum } \\
\text { distillation of } \\
\text { reduced crude oil. }\end{array}$ & $\begin{array}{l}\text { Fraction obtained } \\
\text { from the vacuum } \\
\text { distillation } \\
\text { column of the } \\
\text { reduced crude } \\
\text { obtained by } \\
\text { atmospheric } \\
\text { distillation. }\end{array}$ & $\begin{array}{l}\text { Fraction obtained } \\
\text { by solvent } \\
\text { extraction of the } \\
\text { vacuum } \\
\text { distillation column. } \\
\text { Mainly } \\
\text { alkyl-substituted } \\
\text { aromatics. }\end{array}$ & $\begin{array}{l}\text { Fraction obtained } \\
\text { from cracking, } \\
\text { mainly composed } \\
\text { of alkyl-substituted } \\
\text { hydrocarbons } \\
\text { with aromatic } \\
\text { rings. }\end{array}$ \\
\hline $\begin{array}{c}\text { Density at } 15^{\circ} \mathrm{C} \\
(\mathrm{g} / \mathrm{mL})^{a}\end{array}$ & 0.9090 & 0.9101 & 0.9096 & 0.9409 & 0.9716 \\
\hline $\begin{array}{c}\text { API Gravity } \\
\left({ }^{\circ} \mathrm{API}\right)^{\mathrm{b}}\end{array}$ & 24.1 & 23.9 & 24.0 & 25.1 & 13.5 \\
\hline Saturates (\%) & 82.68 & 53.91 & 62.54 & 59.9 & 43.4 \\
\hline Aromatics (\%) & 16.42 & 45.42 & 35.26 & 39.9 & 53.78 \\
\hline Resins (\%) & 0.90 & 0.67 & 2.20 & 0.20 & 2.80 \\
\hline Asphalthenes (\%) & 0.00 & 0.00 & 0.00 & 0.00 & 0.02 \\
\hline Aniline point $\left({ }^{\circ} \mathrm{C}\right)^{\mathrm{c}}$ & 77.8 & 64.00 & 79.0 & n.d & n.d \\
\hline Sulfur $(w+\%)^{d}$ & 0.191 & 0.931 & 0.830 & 0.50 & 3.36 \\
\hline $\begin{array}{l}\text { Acid number } \\
(\mathrm{mg} \mathrm{KOH} / \mathrm{g})^{\mathrm{e}}\end{array}$ & $<0.100$ & 2.595 & 2.259 & n.d & n.d \\
\hline
\end{tabular}

a: ASTM D 4052-11, b: ASTM D287-12b, c: ASTM D61 1-12, d: ASTM D4294-10, e: ASTM D664-1 1 a

Table 2. Properties of the crude oils used for CEOR formulation.

\begin{tabular}{|c|c|c|c|c|c|c|}
\hline \multirow{2}{*}{ Crude } & \multicolumn{4}{|c|}{ SARA analysis* } & \multirow{2}{*}{ API } & \multirow{2}{*}{ Viscosity (cp) } \\
\hline & $S$ & A & $\mathbf{R}$ & A & & \\
\hline Yariguí 114 & 23.6 & 42.1 & 28.2 & 6.1 & 18.2 & 57 \\
\hline Lisama 161 & 45.8 & 24.0 & 30.1 & 0.1 & 26.6 & 10 \\
\hline
\end{tabular}

*Values obtained by predictive SARA analysis (Meléndez et al., 2012).

Mass portions (corresponding to oil: acid ratios of $1: 1,2: 1$ and $5: 1)$ of concentrated $\mathrm{H}_{2} \mathrm{SO}_{4}(98 \mathrm{in} \mathrm{wt} \%)$ were added gradually over $50.0 \mathrm{~g}$ of hydrocarbon in an crushed ice bath during one hour. After addition, the temperature reaction was adjusted to $65^{\circ} \mathrm{C}$ and kept for 3 hours. The mixture was stirred in order to obtain a good homogenization. After this operation, the solution was maintained at room temperature for 2 hours and then poured onto a separation funnel with $50 \mathrm{~mL}$ of ice cold water. After decantation, two phases were obtained: The hydrophilic sulphonic acids in the lower phase were recovered, and the upper phase conformed by nonsulfonated hydrocarbons and a lower proportion of lipophilic sulfonic acids was discarded. These sulfonic acids aqueous suspension was then neutralized with a sodium hydroxide $(\mathrm{NaOH})$ solution until a $\mathrm{pH}$ value of $6.5-7$, and extracted with a $40 \%$ isopropanol solution to eliminate inorganic salts (mainly $\mathrm{Na}_{2} \mathrm{SO}_{4}$ ). The obtained product was concentrated by removing the alcohol/water mixture from solution using a rotating evaporator. The obtained petroleum sulfonates and their corresponding raw materials are related in Table 3 . 
Table 3. Codification of surfactants used for CEOR formulation obtained from the different distillates.

\begin{tabular}{|ccccccc|}
\hline Surfactant code & 1, 2 and 3 & 4 & 5 & 6 & 7 \\
\cline { 2 - 6 } Petroleum distillate & LVGO & BN-100H & HVGO & LCO & DMO \\
\cline { 2 - 5 } & & &
\end{tabular}

\section{Characterization of Petroleum Sulfonates}

The chemical structures of the obtained surfactants 1-7 were proposed after analizing the spectra from a Shimadzu Prestige 21 MIR-ATR Fourier Transform infrared spectrophotometer and a HACH-DR5000 UV spectrophotometer $(200 \mathrm{~nm}$ to $280 \mathrm{~nm})$. The sulfonates average molecular weight and the aromatic rings distibution of their hydrophobic chains were determined by High Temperature Simulated Distillation Mass Spectroscopy (HTSD-MS) (Villalanti, Raia \& Maynard, 2000) using an Agilent 57890a Gas Chromatograph equipped with a Hewlett Packard Flame Ionization Detector (FID-Avondale, PA) and a HP 5972 Mass Selective Detector. Hydrocarbon standards and polywax sample were used for boiling range calibration covering carbon numbers from $\mathrm{C}_{14}$ to $\mathrm{C}_{100}$. Following an approach similar to ASTM method D5307-97(2007), the retention time was transformed to the temperature and the response to sample mass. All samples were diluted with carbon disulfide $(1: 100, \mathrm{~m} / \mathrm{v})$ before they were injected on a non-polar $5 \mathrm{~m} \times 0.53 \mathrm{~mm}$ ID capillary column coated with BPX1 $(0.1 \mu \mathrm{m}$ of $100 \%$ Dimethyl Polysiloxane). According to literature, for all quantitative and instrumental analysis described above, the petroleum sulfonates here obtained were subjected to a dehydring, deoiling, and desalting procedure in order to avoid non-sulfonated hydrocarbon signals in spectral and chromatographic analysis (Basu \& Shravan, 2008; Harban \& Johnson, 1963). For HTSD purposes, a desulfonation process was additionally performed over the obtained products according to reported procedures (Lee \& Puttnam, 1967).

The active matter content in the obtained sulfonates was determined by potentiometric titration using an universal application Tritrino plus 848, with an anionic surfactants selective electrode (Surfatrode 6.0507.120) and using TEGO-Trant ${ }^{\circledR}$ as titrating agent (Sánchez \& del Valle, 2005).

Phase Behavior Tests for the Evaluation of the Hydrophilic Lipophilic Nature of the Petroleum Sulfonates. The Sigma Parameter

The sigma values for the prepared petroleum sulfonates were calculated using the HLD equation and the mixing rule (See Equation 1).

The optimum salinity for each sulfonate was determined by performing salinity scans (oil/surfactants/ brine) according to Salager et al. (2006). Different tubes were filled separately with solutions containing $1 \%$ petroleum sulfonate $1-7$, and variating the $\mathrm{NaCl} \%$ in the water phase at room temperature $\left(25^{\circ} \mathrm{C}\right)$. Each set of tubes was mixed and the formation of microemulsions between the formulations and n-heptane as the oil phase was observed over time. The optimum salinity was chosen as the $\mathrm{NaCl}$ concentration at which the volume of water within the microemusion equals the volume of oil within the microemulsion $(H L D=0)$. These salinity values were used to calculate the sigma values according to the HLD equation mentioned above.

\section{Assesment of the Sinthesized Sulfonates for Potential use in CEOR}

According to preliminary formulation analysis, when using formulations with up to $1.0 \mathrm{wt} \%$ in the aqueous phase of petroleum sulfonate 1-7, Winsor III type systems are not observed in the transition between Winsor I and Winsor II phase behavior types. One or more features of the sulfonates make them unable to solubilize oil and water by themselves. For this reason, all sulfonates were evaluated as a secondary surfactant in the subsequent analysis here reported.

In order to define the surfactant mixing ratio capable to perform the higher solubilization of oil and water at the optimum (higher SR), a series formulations (oil/surfactants/brine) were prepared according to the procedure of salinity scans. Different sets of test tubes were filled with solutions containing Petrostep S13D $\left(C_{16-17}-\mathrm{PO}_{13}-\mathrm{SO}_{4}\right)$ as the primary surfactant (because of its known solubilizing ability) and Sulfonate 4 as secondary, at different ratios (total surfactant concentration $1 \mathrm{wt} \%$ in the aqueous phase), and varying the salinity $(\mathrm{NaCl} \%)$ and then adding Lisama-161 crude oil in a water-to-oil ratio of 3 . Each set of tubes was mixed and then observed over time at $52^{\circ} \mathrm{C}$. The surfactant 
blend generating the formation of microemulsion middle phase and the greater SR was chosen as the surfactant ratio to employ within formulations, and by using different petroleum sulfonates and other crude oils.

\section{RESULTS AND ANALYSIS}

\section{Preparation of Petroleum Sulfonates}

In general, contents between $20 \%$ and $50 \%$ of aromatic compounds favor the formation of sulfonates in concentrations able to reduce the interfacial tension to ultralow values (Almalik et al., 1997). With the purpose of determining the best conditions for the sulfonation reaction, LVGO was selected based on its higher aromatic content in contrast to other petroleum fractions (See Table 1). This sample was subjected to direct sulfonation under different oil/sulfonating agent ratios $\left(\mathrm{H}_{2} \mathrm{SO}_{4}\right)$, which, according to literature, affects the efficiency and the active matter content on the final product. Based upon these results, the best conditions were selected for the preparation of petroleum sulfonates using different raw materials.

Additionally to the aromatic content within the petroleum fraction, during sulfonation it is necessary to control the process in order to guarantee that only one sulfonate group is attached to the hydrocarbon on the final product. Such a control is possible by means of reducing the concentration of the sulfonating agent below the stoichiometric required quantities. These operational factors affect considerably the interfacial properties of the products, and thus, may be considered in order to optimize the reaction process (Basu \& Shravan, 2008).
Table 4 shows the results of sulfonation reactions using LVGO and different oil/sulfonating agent ratios. In agreement to the literature reports, a decrease in the amount of sulfonated matter is observed as the sulfonating agent quantity is reduced.

This can be related to a decline in the polysulfonated hydrocarbons produced during the process (Zhang et al., 2010; Basu \& Shravan, 2008; Djedri et al., 2010). Furthermore, it can be seen that the amount of salts produced during the neutralization procedure (mainly sodium sulfate) is also reduced with the $\mathrm{H}_{2} \mathrm{SO}_{4}$ decrease. It was also observed that the Non-Sulfonated Hydrocarbons (NSHC) increased their weight as the sulfonating agent decreased. This can be understood as a consequence of the formation of lipophilic byproducts that increase the mass of the unreacted fraction (Djedri et al., 2010).

\section{Characterization of Petroleum Sulfonates}

According to the results discused above, the best results were obtained for an oil to sulfuric acid ratio of 5:1 (moderate yield and minor salt production). This condition was selected for the preparation of petroleum sulfonates 4-7 using different raw materials, BN-100H, HVGO, LCO and DMO. Table 5 shows the active matter, water and salt content of the petroleum sulfonates 1-3. It can be observed that higher active matter content is obtained for sulfonate 1 (1:1 Oil to $\mathrm{H}_{2} \mathrm{SO}_{4}$ ratio). However, the sulfonates concentration in weight percentage ( $\mathrm{wt} \%$, gravimetrically determined) is greater, possibly as a consequence of the formation of polysulfonation products of higher molecular weight, but producing a lower molar concentration. The salts and water content in the final products remain around $20 \%$ and $50 \%$, respectively.

Table 4. Petroleum sulfonates preparation using LVGO with different $\mathrm{Oil}: \mathrm{H}_{2} \mathrm{SO}_{4}$.

\begin{tabular}{|ccccc|}
\hline Surfactant & Oil: $\mathrm{H}_{2} \mathrm{SO}_{4} \mathbf{9 8 \%}$ & Yield (\%) & Prod. salts $(\mathbf{g})^{* *}$ & NSHC (g) \\
\hline 1 & $1: 1$ & 45 & 43.77 & 27.52 \\
\hline 2 & $2: 1$ & 33 & 13.30 & 33.53 \\
\hline 3 & $5: 1$ & 23 & 7.06 & 38.78 \\
\hline
\end{tabular}

${ }^{*}$ Calculated from $50 \mathrm{~g}$ GLV (g NSH/50g LVG) X100, **Produced salts in process, ${ }^{* * * N S H C: ~ N o n ~ s u l f o n a t e d ~ h y d r o c a r b o n s ~}$ 
Table 5. Characterization of petroleum sulfonates obtained from LVGO.

\begin{tabular}{|c|c|c|ccc|}
\hline Surfactant & Oil: $\mathrm{H}_{2} \mathrm{SO}_{\mathbf{4}} \mathbf{9 8 \%}$ & Concent. (wt\%)* & Concent. (mol/L)** & Salts (wt\%) & $\mathrm{H}_{2} \mathrm{O}(\mathrm{wt} \%)$ \\
\hline 1 & $1: 1$ & 30 & 1.46 & 25 & 45 \\
\hline 2 & $2: 1$ & 23 & 2.12 & 20 & 57 \\
\hline 3 & $5: 1$ & 22 & 2.24 & 21 & 57 \\
\hline
\end{tabular}

${ }^{*}$ Calculated gravimetrically from $50 \mathrm{~g}$ of sulfonates.

**Determinated by potentiometric titration [30].

Table 6. Characterization of petroleum sulfonates obtained from different distillation fractions using Oil: $\mathrm{H}_{2} \mathrm{SO}_{4}$ equal to $5: 1$.

\begin{tabular}{|ccccccc|}
\hline Surfactant & Distillation fraction & Concent. (wt\%) & Concent. (mol/L)** & Salts (wt\%) & $\mathrm{H}_{2} \mathrm{O}(\mathrm{wt} \%)$ \\
\hline 4 & $\mathrm{BN}-10 \mathrm{OH}$ & 12 & 1.46 & 25 & 63 \\
\hline 5 & $\mathrm{HVGO}$ & 5.0 & 0.56 & 21 & 74 \\
\hline 6 & $\mathrm{LCO}$ & 12 & 1.42 & 20 & 68 \\
\hline 7 & $\mathrm{DMO}$ & 0.15 & $\leq 0.001$ & 35 & 65 \\
\hline
\end{tabular}

Table 6 shows the results for the sulfonation reactions performed on different distillation fractions.

The lowest active matter concentration was observed for sulfonates 5 and 7 . This is possibly due to the formation of high Molecuar Weight (MW) sulfonic acids produced by the higher MW of the sulfonable hydrocarbons present in the HVGO and the DMO. Consequently, as these sulfonic acids become more lipophilic, they will be retained in the oil phase and their corresponding sodium sulfonates can not be quantified within the aqueus layer after the neutralization process.

\section{Spectral Analisys}

The espectral analisys by UV-Vis is shown in Figure $2 \mathrm{a}$ and $2 \mathrm{~b}$. Product 7 was not tested because of its low active material content. It is noticed that the maximum absorption band of sulfonates obtained from $\mathrm{BN}-100 \mathrm{H}$, LVGO, HVGO and LVCO is between $210 \mathrm{~nm}$ and 275 $\mathrm{nm}$. This indicates the presence of aromatic compounds (220 nm - $280 \mathrm{~nm}$ ) (Basu \& Shravan, 2008; Djedri et al., 2010; Sandvik et al., 1977). However, the maximum absortion bands for the UV spectrums of products 1-3 and 6 are present around $230 \mathrm{~nm}$, indicating a major content on double-ring aromatic nuclei within these sulfonates structures $(230 \mathrm{~nm})$, followed by single-ring
$(210 \mathrm{~nm})$ and a relatively lower content of triple-ring sulfonates (260 nm) (Cross, 1998). For comparative prupouses, the UV espectra of comercial petroleum sulfonates are shown in Figure 2c.

Figure 3 presents the FTIR spectrums of petroleum sulfonates 3-7. Coherently with the results reported by Djedri et al. (2010), the para-sulfonic group is observed around $1176 \mathrm{~cm}^{-1}$ and $1045 \mathrm{~cm}^{-1}$. Aditionally, characteristic signals of methylene and methyl groups are observed in $2950 \mathrm{~cm}^{-1}$ and $2850 \mathrm{~cm}^{-1}$, and between $1450-1377 \mathrm{~cm}^{-1}$.

\section{Average Molecular Weight and the Aromatic Rings Distribution}

In an attempt to determine the average molecular weight and to confirm the structural characteristics of the obtained petroleum sulfonates 1-7, a High Temperature Simulated Distillation analysis (HTSD) to the hydrophobic chain of our surfactants was performed. For this purpose, a deoiled, desalted and dehydrated sample of each sulfonate was subjected to a hydrolysis procedure using refluxing concentrated phosphoric acid for $3 \mathrm{~h}$, then extracted with n-hexane and analyzed by HTSD (Villalanti et al., 2000). 


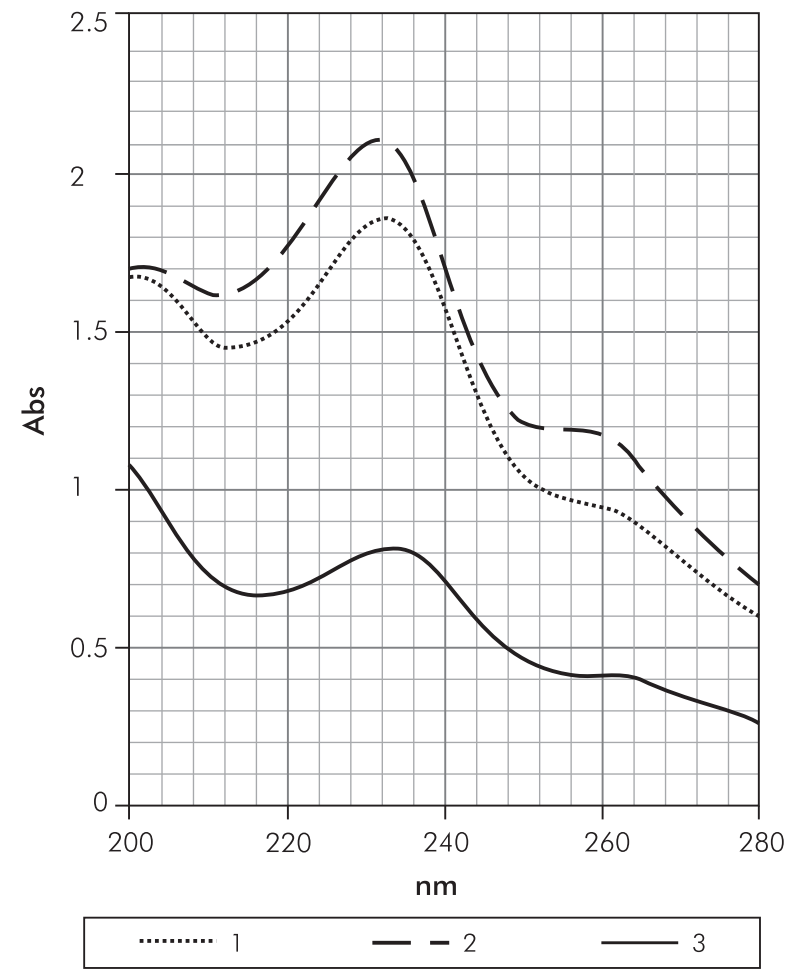

(a)

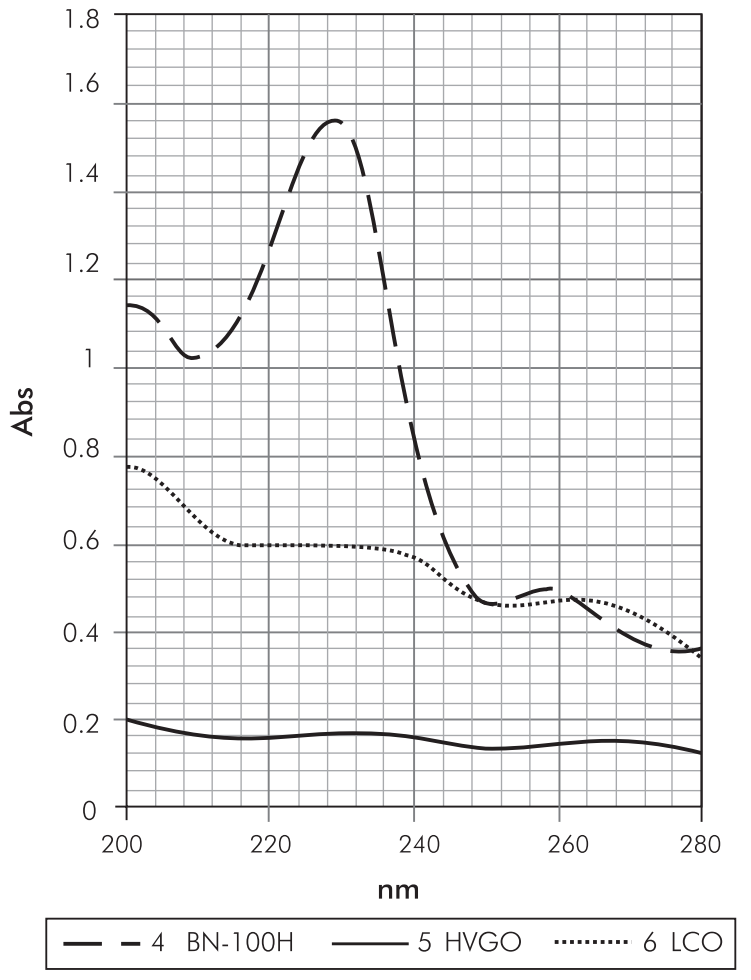

(b)

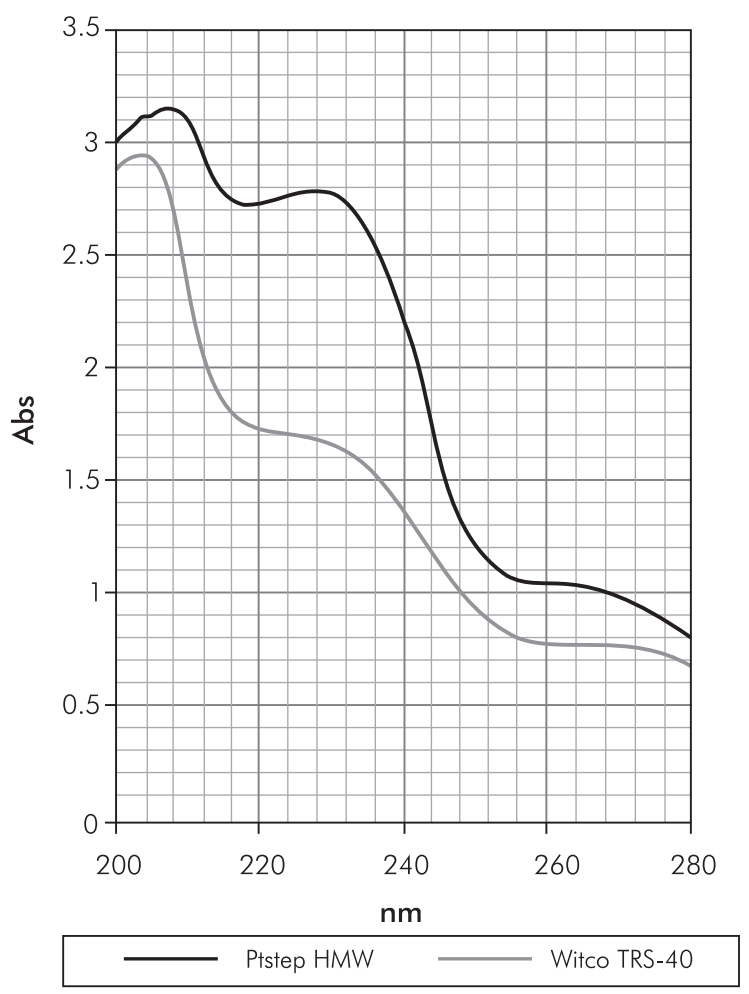

(c)

Figure 2. UV adsorption of the prepared petroleum sulfonate surfactants. a) Sulfonates obtained from LVGO, b) Sulfonates obtained from three different distillates (BN-100H, HVGO, LCO), c) Commercial petroleum sulfonates Petrostep ${ }^{\circledR}$ HMW and Witco ${ }^{\circledR}$ TRS -40 . 


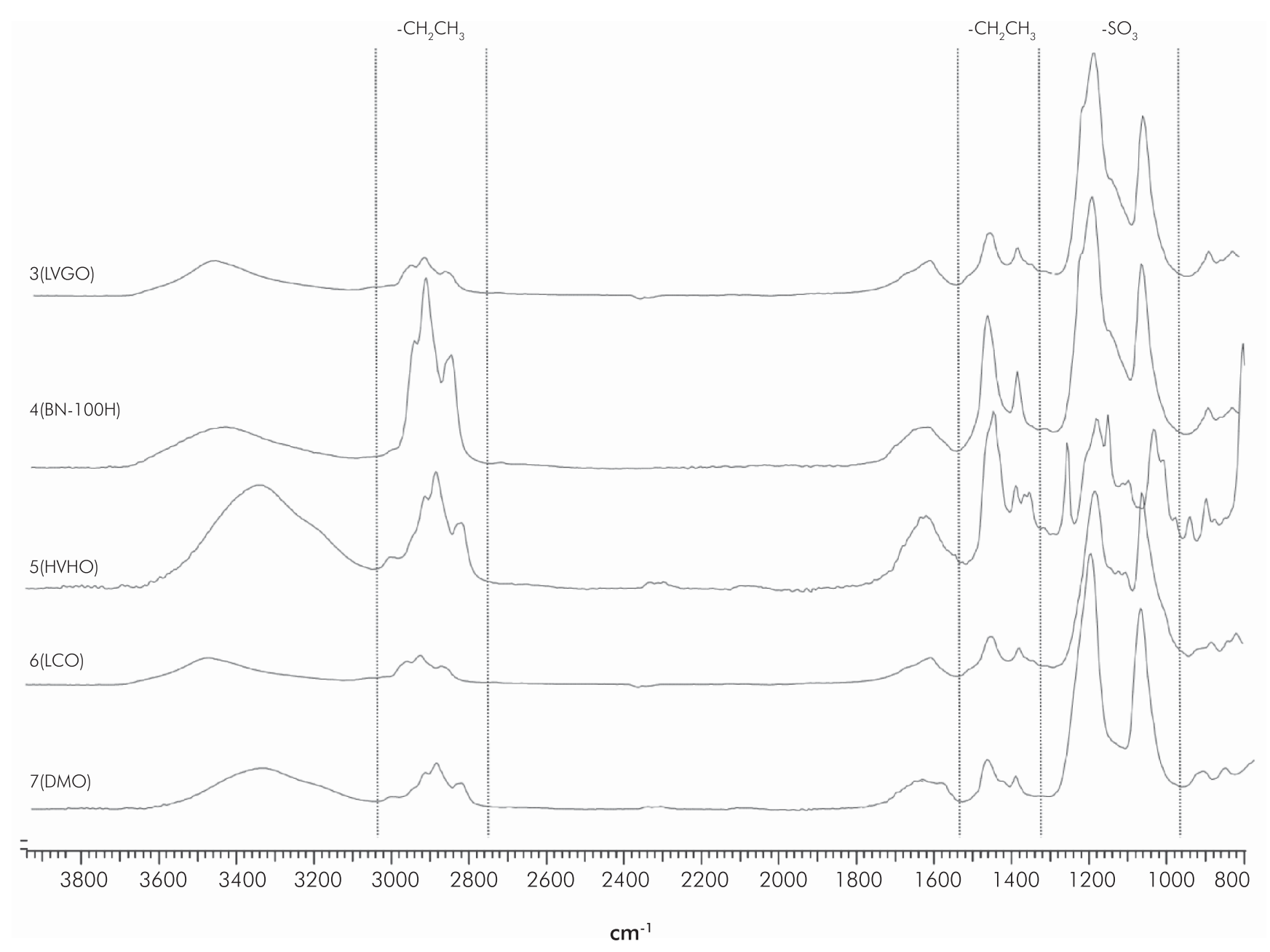

Figure 3. Infrared spectrums of the different petroleum sulfonate surfactants prepared from different petroleum distillates.

Table 7 shows the average MW and the compositional distribution of the hydrocarbons that are sulfonated under the stablished reaction conditions for each petroleum sulfonate. Product 7 is not shown in this analysis because of its low active matter content. For comparative purposes, the HTSD of commercial petroleum sulfonates Petrostep ${ }^{\circledR} \mathrm{HMW}$ and Witco ${ }^{\circledR}$ TRS-40 were performed and included.

According to these results, larger amounts of sulfonating agent increase the average MW as it is observed for sulfonates 1-3 obtained from LVGO using different Oil: $\mathrm{H}_{2} \mathrm{SO}_{4}$ ratios. Apparently, lower Oil: $\mathrm{H}_{2} \mathrm{SO}_{4}$ ratios allow the sulfonation of large amounts of saturated hydrocarbons and a reduced amount of polyaromatic rings, producing petroleum sulfonates of higher MW 1 and 2 compared with sulfonate 3 with $37.79 \%$ saturate and $11.60 \%$ monoaromatic hydrocarbons. However, it must be considered that large quantities of $\mathrm{H}_{2} \mathrm{SO}_{4}$ can result on higher polysulfonation products and a 5:1 ratio was selected based on these results. Moreover, it can be observed that using different refinery cuts under a 5:1 Oil to $\mathrm{H}_{2} \mathrm{SO}_{4}$ ratio, a higher molecular weight is reached as the raw material MW increases.

HTSD-MS analysis allowed us to confirm the interpretations made based on the FTIR and UV results. In contrast to the petroleum sulfonates obtained from $\mathrm{BN}-100 \mathrm{H}$ (7) and $\mathrm{ALC}$ (6), a higher paraffinic structure is achieved for the sulfonates prepared using HVGO (5). Furthermore, products 4 and 5 showed to have hydrophobic extensions with a higher content of singlering aromatic hydrocarbons followed by double-ring and triple-ring aromatics. Surfactant 6 presented the highest content of double-ring systems (Naphthalene). 
Table 7. Average MW and compositional distribution of hydrocarbons present in petroleum sulfonates 1-6.

\begin{tabular}{|c|c|c|c|c|c|c|c|c|}
\hline \multirow{2}{*}{ Composition (\%) } & \multicolumn{8}{|c|}{ Petroleum Sulfonate } \\
\hline & 1 (LVGO) & 2 (LVGO) & 3 (LVGO) & 4 (BN100H) & 5 (HVGO) & $6(\mathrm{LCO})$ & TRS-40 & Ps HMW \\
\hline Average $\mathrm{MW}(\mathrm{Da})$ & 428 & 423 & 392 & 370 & 412 & 325 & 343 & 536 \\
\hline Saturates & 56.50 & 56.47 & 37.79 & 1.20 & 38.76 & 4.81 & 17.63 & 27.94 \\
\hline Paraffins & 2.00 & 1.90 & 0.00 & 0.00 & 5.37 & 0.00 & 0.00 & 0.00 \\
\hline Monocycloparaffins & 0.00 & 0.00 & 0.00 & 0.00 & 9.34 & 0.00 & 0.00 & 0.00 \\
\hline Dicycloparaffins & 41.61 & 42.61 & 37.79 & 1.20 & 5.91 & 1.59 & 17.63 & 24.37 \\
\hline Tricycloparaffins & 12.00 & 11.96 & 0.00 & 0.00 & 18.14 & 3.22 & 0.00 & 3.57 \\
\hline Aromatics & 42.85 & 43.53 & 61.85 & 98.80 & 61.24 & 95.19 & 82.37 & 72.06 \\
\hline Monoaromatics & 16.53 & 16.53 & 11.60 & 24.95 & 20.23 & 16.81 & 47.59 & 44.80 \\
\hline Alkyl benzenes & 2.29 & 2.29 & 2.00 & 0.00 & 1.13 & 1.46 & 13.89 & 16.61 \\
\hline Naphthene benzenes & 6.49 & 6.49 & 4.03 & 7.52 & 1.26 & 10.23 & 17.89 & 14.34 \\
\hline Dinaphthene benzenes & 7.75 & 7.75 & 5.57 & 17.43 & 17.84 & 5.12 & 15.80 & 13.85 \\
\hline Diaromatics & 24.80 & 24.56 & 27.03 & 24.99 & 7.59 & 51.57 & 18.71 & 9.58 \\
\hline Naphftalenes & 21.21 & 21.21 & 14.36 & 7.54 & 4.68 & 33.42 & 7.62 & 4.49 \\
\hline Acenaphthenes, Dibenzofuranes & 2.03 & 2.03 & 6.21 & 10.77 & 2.20 & 11.91 & 6.69 & 0.00 \\
\hline Fluorenes & 1.32 & 1.32 & 6.47 & 8.68 & 0.70 & 6.24 & 4.40 & 5.09 \\
\hline Triaromatics & 0.00 & 0.00 & 11.95 & 20.20 & 15.64 & 13.92 & 5.05 & 2.70 \\
\hline Phenanthrenes & 0.00 & 0.00 & 11.84 & 11.91 & 8.55 & 13.32 & 4.07 & 2.70 \\
\hline Naphthene phenanthrenes & 0.00 & 0.00 & 0.11 & 8.29 & 7.09 & 0.58 & 0.97 & 0.00 \\
\hline Tetraromatics & 0.45 & 0.42 & 2.68 & 13.36 & 14.22 & 1.98 & 2.94 & 1.68 \\
\hline Pyrenes & 0.45 & 0.42 & 2.68 & 10.26 & 10.36 & 1.89 & 1.46 & 1.03 \\
\hline Crysenes & 0.00 & 0.00 & 0.00 & 3.10 & 3.86 & 0.09 & 1.48 & 0.65 \\
\hline Pentaromatics & 0.00 & 0.00 & 0.00 & 2.15 & 0.00 & 0.52 & 0.70 & 0.00 \\
\hline Perylenes & 0.00 & 0.00 & 0.00 & 0.00 & 0.00 & 0.34 & 0.70 & 0.00 \\
\hline Thiophene Aromatics & 2.02 & 2.02 & 8.58 & 7.32 & 2.11 & 10.20 & 5.82 & 8.26 \\
\hline Benzothiophenes & 1.48 & 1.54 & 5.74 & 0.47 & 0.00 & 8.08 & 2.59 & 5.37 \\
\hline Dibenzothiophenes & 0.54 & 0.48 & 2.81 & 6.85 & 0.00 & 2.10 & 3.16 & 2.80 \\
\hline
\end{tabular}

According to these results, the chemical structure of the petroleum sulfonates depends on the characteristics of the distillate employed. These structural differences may well govern the surface-active properties of the product and thus define its potential applications in CEOR.

\section{Hydrophilic-Lipophilic Nature of the Petroleum Sulfonates. The Sigma Parameter}

The sigma parameter corresponds to a characteristic value for an anionic surfactant at a specific concentration that allows defining its hydrophilic-lipophilic behavior. When two or more surface active substances are compared, a high value of sigma indicates a lipophilic character.

For all the sulfonates surfactants that were synthesized and evaluated, a considerable volume of middle phase microemulsion was not obtained in the salinity range of the transition from Winsor I to Winsor II, even at relatively high concentrations of surfactant. The 
solubilized oil and water employing these sulfonates resulted very low and made the optimum salinity determination difficult. With this in mind, we addressed to employ a mixing rule including a second surfaceactive component in our systems. Using the internal olefin sulfonate Petrostep ${ }^{\circledR} \mathrm{S} 2\left(\mathrm{C}-{ }_{15} \mathrm{C}-{ }_{18} \mathrm{IOS}\right)$ (Wade et al., 1978), it was possible to improve by synergy the SR, and thus detect the optimum salinity. The sigma values for the prepared petroleum sulfonates were calculated using the HLD equation and the mixing rule (Equation 1). The optimum salinity for each sulfonate was then determined by means of salinity scans, according to the methodology described by Salager (1977) and Salager et al. (2006). Table 8 presents the sigma values and the optimum salinities for each of the petroleum sulfonates 1-7. Each scanning was performed using n-heptane as the organic phase, and a total surfactant concentration of $1 \%, 0.75 \%$ corresponding to Petrostep ${ }^{\circledR}$ S2 and $0.25 \%$ to the evaluated petroleum sulfonate. The temperature $\left(25^{\circ} \mathrm{C}\right)$, water to oil radio (WOR $\left.=1\right)$, and the nature and amount of alcohol (n-pentanol 2\%) were kept constant (Table 8).

According to the sigma values, the petroleum sulfonates prepared are highly hydrophilic. The same classification can be achieved by comparing the salinity values with that of the Sodium Dodecyl Benzene Sulfonate (SDBS). The optimal salinity is the salinity at which surfactant migrates from the aqueous phase (Winsor I) to the oil phase (Winsor II). If the system has the classical Winsor phase behavior, a middle phase microemulsion (Winsor III) is observed in the transition between Winsor I and Winsor II phase behavior. The optimal salinity is lower for lipophilic surfactants and is higher for hydrophilic surfactants (Winsor, 1954). Furthermore, it can be observed that more lipophilic sulfonates can be obtained as a larger amount of sulfonating agent $\left(\mathrm{H}_{2} \mathrm{SO}_{4}\right)$ is employed during the synthesis (1), possibly because a major portion of heavier hydrocarbons are sulfonated under the established conditions. Products 6 and 7 resulted to be the most hydrophilic surfactants within the series of sulfonates prepared. This can be due to the presence of a major content of aromatic hydrocarbons with short aliphatic chains in the raw materials employed for their preparation.

\section{Evaluation of the Petroleum Sulfonates Obtained as Potential CEOR Surfactants for Yariguí and Lisama Crude Oils}

Although the surfactants here obtained are highly hydrophilic, and since they are no able to solubilize oil and water in a middle microemulsion phase, it is possible to consider that they could improve their performance if they are used combined with different surfactants of more lipophilic nature. Such synergistic phenomena have been reported in literature and have shown to accomplish formulations able to reduce the interfacial tension down to ultralow values (El-Batanoney et al., 1999; Comelles, Sánchez-Leal \& González, 2007; Wu et al., 2005; Gregersen, Kazempour \& Alvarado, 2013).

Table 8. Sigma values of the obtained petroleum sulfonates.

\begin{tabular}{|c|c|c|c|c|c|}
\hline Surfactant & Raw material & Oil: $\mathrm{H}_{2} \mathrm{SO}_{4}$ & $M V(g / m o l)$ & $\begin{array}{l}\text { Optimum salinity } \\
(\% \mathrm{NaCl})\end{array}$ & Sigma $\sigma$ \\
\hline 1 & LVGO & $1: 1$ & 435 & 2.4 & -2.01 \\
\hline 2 & LVGO & $2: 1$ & 432 & 3.3 & -3.28 \\
\hline 3 & LVGO & $5: 1$ & 392 & 3.7 & -3.74 \\
\hline 4 & $\mathrm{BN}-100 \mathrm{H}$ & $5: 1$ & 370 & 2.9 & -2.76 \\
\hline 5 & HVGO & $5: 1$ & 412 & 3.0 & -2.90 \\
\hline 6 & $\mathrm{LCO}$ & $5: 1$ & 325 & 4.0 & -4.05 \\
\hline 7 & $\mathrm{DMO}$ & $5: 1$ & n.d & 4.2 & -4.24 \\
\hline Petrostep ${ }^{\circledR}$ S2 & $\cdots$ & $\cdots$ & 348 & 0.5 & -1.66 \\
\hline SDBS* & $\ldots$ & 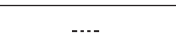 & 283 & 0.5 & -0.60 \\
\hline
\end{tabular}

*SDBS $=$ Sodium Dodecyl Benzene Sulfonate 
An optimal formulation is defined as the state in which, the conjunction of external and compositional variables is such that a minimum of interfacial tension is produced. Among the characteristic properties of an optimal formulation, the tri-phasic behavior, a Winsor's $\mathrm{R}=1$ (Winsor III system behavior), a similar solubilization of water and oil by action of the surfactant in the middle phase microemulsion, are the essential. According to the results discussed above, the petroleum sulfonates obtained are highly hydrophilic, possibly due to the conditions present on the extraction stage, and are not able to show a significant solubilization of the organic phase (Crude or Heptane). For this reason, we decided to evaluate their potential usage as secondary surfactant, in an attempt to identify any synergic effect in combination with other surfactant products.

In this work, the petroleum sulfonates 1-6 were evaluated against the Colombian crude oils Yariguí 114 and Lisama 161. When using blends of Petrostep ${ }^{\circledR}$ S2 and our sulfonates, with crude-oil as the organic phase, Winsor III systems were not found. Thus, several commercial surfactants were tested, among them the Petrostep ${ }^{\circledR}$ S13D, and an alkyl propoxy sulfate surfactant $\left(\mathrm{C}_{16^{-18}} \mathrm{PO}_{13} \mathrm{SO}_{4}\right.$ ) (Gregersen et al., 2013; Wu et al., 2005; Carmona, Schechter, Wade \& Weerasooriya, 1985) that showed good synergy with the petroleum sulfonates, probably due to inter and intramolecular extension of the interphase (Salager et al., 2013). In order to determine the surfactant mixing ratio performing the maximum solubilization of oil and water, sulfonate 4 was randomly selected and evaluated with Lisama-161 in different sulfonate to Petrostep ${ }^{\circledR}$ S13D ratios (Figure 4). For these scans, a temperature of $52^{\circ} \mathrm{C}, \mathrm{WOR}=3$, and a total surfactant concentration of $1 \mathrm{wt} \%$ in the aqueous phase was kept constant. No alcohol, alkali or polymer was included in these systems. The crudes here employed were selected based on their properties (API Gravity, Viscosity and SARA composition) and because they are part of the oil fields of interest for this project. Figure 4 shows the optimum salinity and SR as a function of the petroleum sulfonate 4 in weight percent (\% of 4$)$, within the blends composed by 4 and Petrostep ${ }^{\circledR}$ S13D, using Lisama-161 oil.

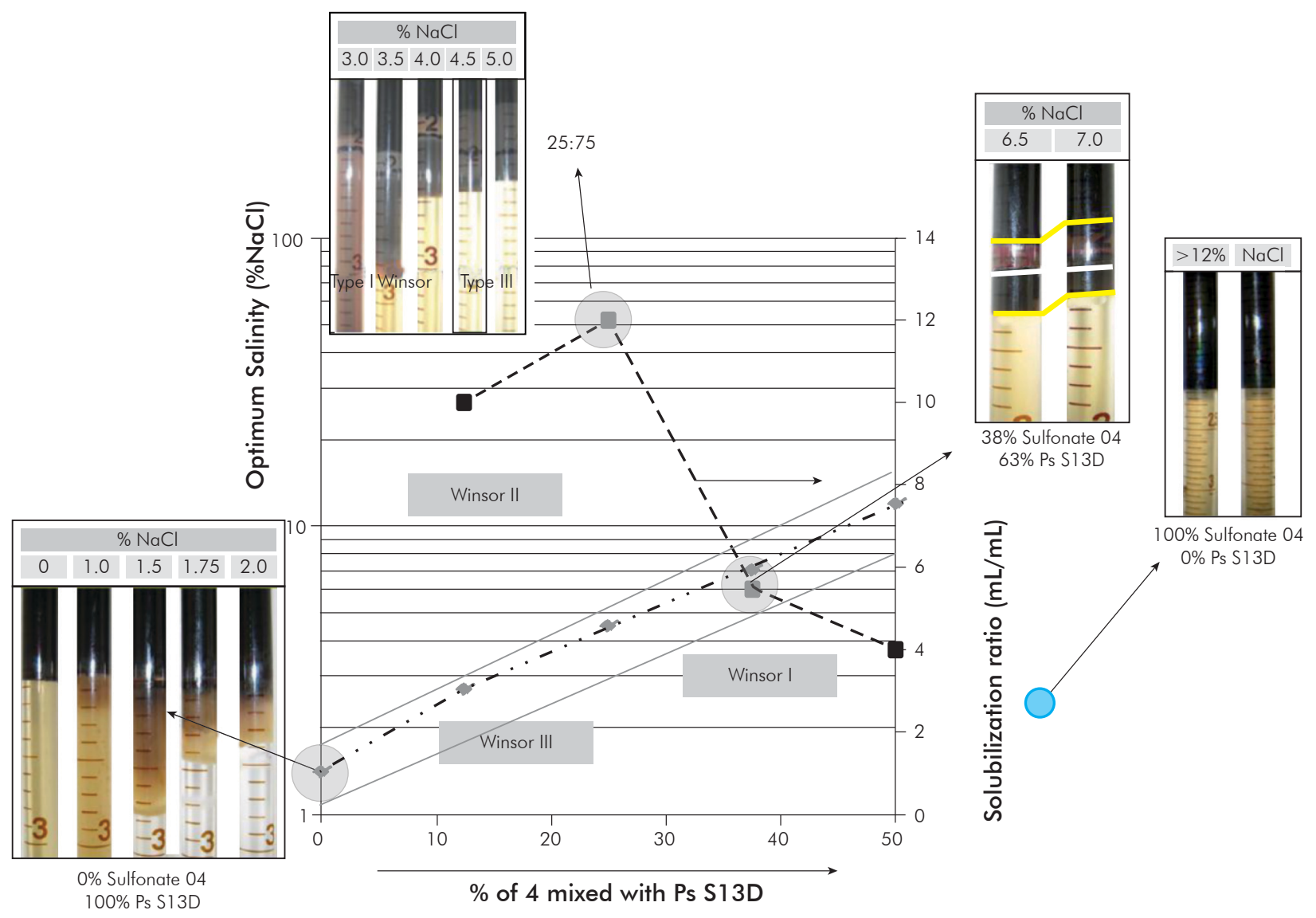

Figure 4. Optimum salinity and SR as a function of the petroleum sulfonate 4 in weight percentages total surfactant concentration PsS13D + PS4 $=1 \mathrm{w}+\%$ in the aqueous phase. Temperature: $52^{\circ} \mathrm{C}$, Water/Oil ratio $=3$. Organic Phase: Lisama- 161 crude oil. 
According to Chun Huh's equation, when SR $>10$ the interfacial tension is lower than $3 \times 10^{-3} \mathrm{mN} / \mathrm{m}$. For the systems showed in Figure 4, this condition is valid only for blends containing no more than 35\% PS4. A 25:75 of PS to Petrostep ${ }^{\circledR}$ S13D ratio was chosen, considering that a maximum SR was observed near this relation. Once a good primary (PsS13D) to secondary surfactant (PS) mixing ratio was defined, it is simplistically assumed that it would be good enough for the assessment of the behavior of other petroleum sulfonates 1-6 and with other crude oils. Product 7 was excluded due to its low active matter concentration.

Figure 5 shows the optimum salinity for the petroleum sulfonates obtained from four different raw materials in mixtures with Petrostep ${ }^{\circledR}$ S13D 25:75. It can be noticed that, with two crude oils, there is a regular augment in the optimum salinity as the sigma of the sulfonates is lower (it is more hydrophilic) as expected (See Table 6).
Additionally, Figure 6 shows the corresponding SR. It can be observed that for Lisama-161 the SR increases, as the secondary surfactant employed is less hydrophilic 4, whereas for Yariguí-114 the SR is high when the formulation contains the most hydrophilic petroleum sulfonate 6 . These results can be associated with the crude oils composition. The presence of a less hydrophilic secondary surfactant (4 or 5) favors the solubilization of relatively more paraffinic crudes (Lisama). According to the structural characterization performed, these two sulfonates present longer carbon chains and a major proportion of single-ring aromatic nuclei, conferring them a lower hydrophilic nature and thus, a feasible interaction with an oil of a higher EACN or more paraffinic. In the same way, more aromatic crudes (Yariguí) require less lipophilic surfactants similar to the products 1 or 6 (See Table 6), which according to the structural analysis, have a shorter carbon chain and a major content of double-ring aromatic systems that allow the interaction with crudes of a minor EACN or more aromatic.

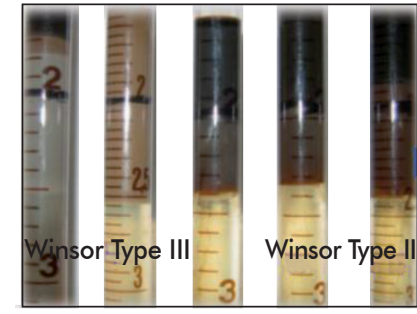

Lisama-161 Crude/Sulfonate 04

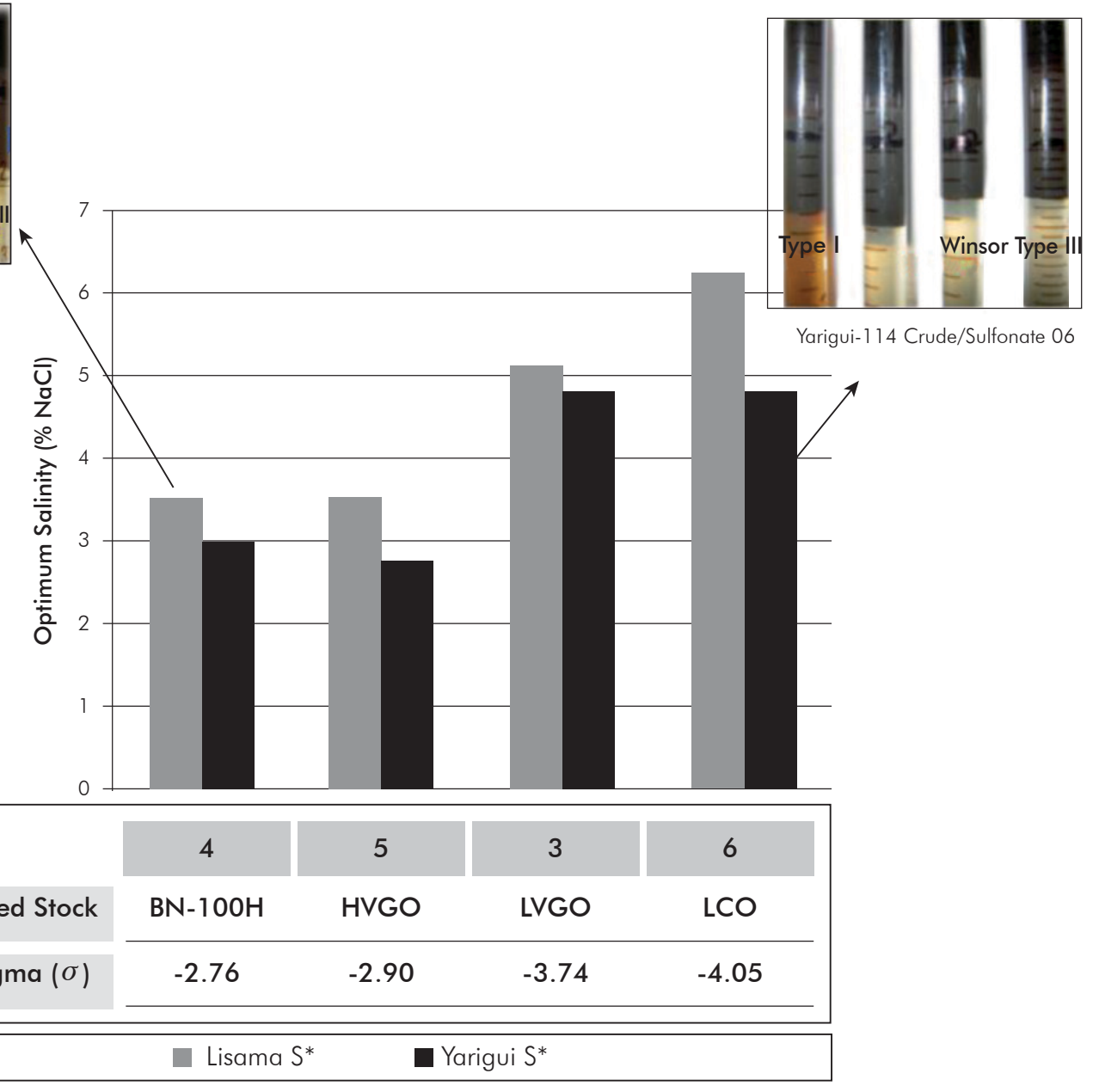

Figure 5. Optimum salinity for formulations containing a fraction of petroleum sulfonates prepared from four different refinery cuts from Barrancabermeja Refinery in Colombia, and Lisama and Yariguí crude oils. 


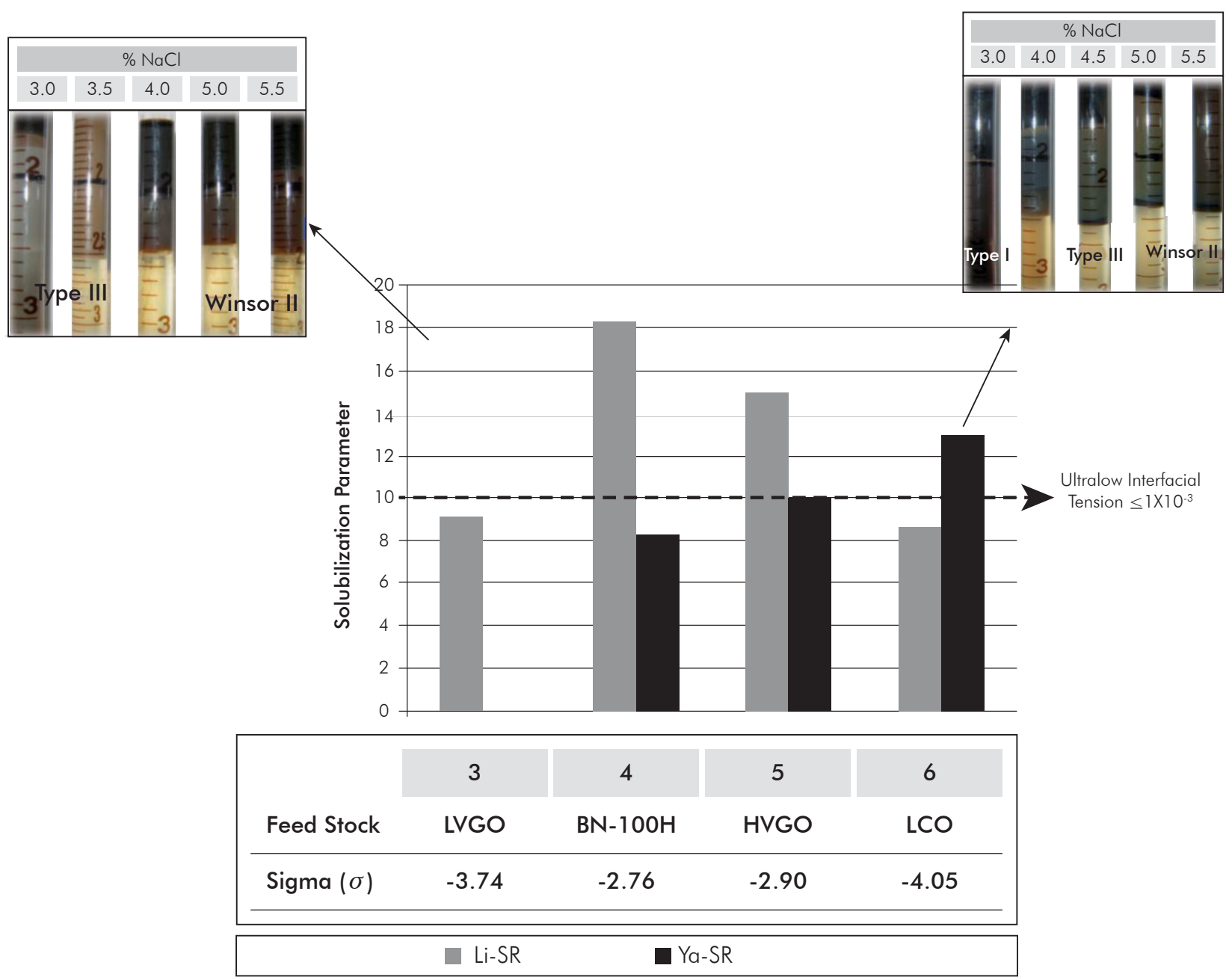

Figure 6. SR for the sulfonates 3-6 obtained from four different refinery cuts from Barrancabermeja Refinery in Colombia assessed with Lisama and Yariguí crude oils.

Based on these results it is possible to consider that, depending on the oil properties, the petroleum sulfonates used as secondary surfactant in oil recovery formulations allow to achieve relatively high SR. Moreover, when applying the Chun Huh's equation it is possible to predict the Interfacial Tension (IFT) for the water/oil systems discussed above (Table 9) (Huh, 1979).

Table 9. Predicted values of interfacial tensions for water/oil systems containing petroleum sulfonates 3-6.

\begin{tabular}{|ccccc|}
\hline Surfactant & SR Lisama & IFT (dynes/cm)* & SR Yariguí & IFT (dynes/cm)* \\
\hline 3 & 9.15 & $3.6 \times 10^{-3}$ & 11 & $2.5 \times 10^{-3}$ \\
\hline 4 & 18.3 & $9.0 \times 10^{-4}$ & 8.3 & $4.4 \times 10^{-3}$ \\
\hline 5 & 15 & $1.3 \times 10^{-3}$ & 10 & $3.0 \times 10^{-3}$ \\
\hline 6 & 8.6 & $4.1 \times 10^{-3}$ & 13 & $1.8 \times 10^{-3}$ \\
\hline
\end{tabular}

*Values calculated by the Chun Huh equation $\left(\mathrm{IFT}=0.3 /(\mathrm{SR})^{2}\right)$. 
The predicted IFT values show that, according to the parameters studied so far, it is possible to design formulations with a potential application in CEOR using petroleum sulfonates prepared from raw materials from Colombian refineries as secondary surfactants. There is room for improvements, for example concerning the yield of the reaction and the extraction process of the sulfonates, the attainment of not-so-hydrophilic products, and the search for specific surfactant blend ratios for maximum performance according to molecular structure of the sulfonates or crude oil characteristics at the lowest possible price per unit mass of surfactant used, but these subjects are out of the scope of this work.

\section{CONCLUSIONS}

- A process for the preparation of petroleum sulfonates and the characterization of their molecular structure, by means of spectral analysis, was completed. It is concluded that, depending on the ratio of sulfuric acid to oil raw material, and on the chemical composition of the refinery cut employed, the surfactant obtained had a larger or shorter hydrophobic moitie, with mono, di or tri aromatic cycles. It could also be mono or poly sulfonated and consequently be more or less hydrophilic/ lipophilic. The process followed in this work yielded mostly highly hydrophilic surfactants, possibly due to the conditions present on the extraction stage.

- Regarding the CEOR formulation evaluation, the solubilization ratio increases as the structural likeness between the crude oil molecules and the lipophilic ends of the petroleum sulfonates increases. It was demonstrated that, when they are used as secondary surfactants, the petroleum sulfonates here prepared allow achieving relatively high solubilization ratios, near or above $10 \mathrm{~mL} / \mathrm{mL}$, which means that ultralow interfacial tension values are attained. Such a property is required for mobilization of trapped residual oil out of porous media.

\section{ACKNOWLEDGEMENTS}

The authors would like to thank Engineer Gustavo Maya-Toro and leading staff for the project Procesos de Recobro Químico Yarigui Cantagallo Ecopetrol S.A. - Instituto Colombiano del Petróleo (ICP) for the financial support, as well as Laboratorio de Química de Producción (Ecopetrol S.A. - ICP) for the SARA analysis of crude samples and to Engineers Cesar A. Mahecha and Héctor J. Picón (Ecopetrol S.A. - ICP) for the samples and information concerning refinery materials employed in this study.

\section{REFERENCES}

Almalik, M. S., Attia, A. M. \& Jang, L. K. (1997). Effects of alkaline flooding on the recovery of Safaniya crude oil of Saudi Arabia. J. Petrol. Sci. Eng., 17(3-4), 367-372.

ASTM D287-12b. Standard Test Method for API Gravity of Crude Petroleum and Petroleum Products (Hydrometer Method). Annual Book of ASTM Standards, Vol. 05.01, ASTM International, West Conshohocken, PA, 2012.

ASTM D611-12. Standard Test Methods for Aniline Point and Mixed Aniline Point of Petroleum Products and Hydrocarbon Solvents. Annual Book of ASTM Standards, Vol. 05.01, ASTM International, West Conshohocken, PA, 2012.

ASTM D664-11a. Standard Test Method for Acid Number of Petroleum Products by Potentiometric Titration. Annual Book of ASTM Standards, Vol. 05.01, ASTM International, West Conshohocken, PA, 2011.

ASTM D2007-11. Standard Test Method for Characteristic Groups in Rubber Extender and Processing Oils and Other Petroleum-Derived Oils by the Clay-Gel Absorption Chromatographic Method. Annual Book of ASTM Standards, Vol. 05.01, ASTM International, West Conshohocken, PA, 2011.

ASTM D4294-10. Standard Test Method for Sulfur in Petroleum and Petroleum Products by Energy Dispersive X-ray Fluorescence Spectrometry. Annual Book of ASTM Standards, Vol. 05.02, ASTM International, West Conshohocken, PA, 2010.

ASTM D4052-11. Standard Test Method for Density, Relative Density, and API Gravity of Liquids by Digital Density Meter. Annual Book of ASTM Standards, Vol. 05.02, ASTM International, West Conshohocken, PA, 2011. 
ASTM D5307-97(2007), Standard Test Method for Determination of Boiling Range Distribution of Crude Petroleum by Gas Chromatography (Withdrawn 2011). Annual Book of ASTM Standards Replaced by D7169. ASTM International, West Conshohocken, PA, 2007.

Babadagli, T., Al-Bemani, A., Boukadi, F. \& Al-Maamari, R. A. (2005). A laboratory feasibility study of dilute surfactant injection for the Yibal field, Oman. J. Petrol. Sci. Eng., 48(1-2), 37-52.

Babadagli, T. \& Boluk, Y. (2005). Oil recovery performances of surfactant solutions by capillary imbibition. J. Colloid Interface Sci., 282(1), 162-175.

Basu, S. \& Shravan, S. (2008). Preparation and characterization of petroleum sulfonate directly from crude. Pet. Sci. Technol., 26(13), 1559-1570.

Bourrel, M., Graciaa, A., Schechter, R. S. \& Wade, W. H. (1979). The relation of emulsion stability to phase behavior and interfacial tension of surfactant systems. $J$. Colloid Interf. Sci., 72(1), 161-163.

Carmona, I., Schechter, R. S., Wade, W. H. \& Weerasooriya, U. (1985). Ethoxylated oleyl sulfonates as model compounds for enhanced oil recovery. SPE Journal, 25(3), 351-357.

Comelles, F., Sánchez-Leal, J. \& González, J. J. (2007). Soy oil microemulsions made of anionic surfactant, oleic acid, diethyleneglycol ethyl ether, and water: Optimized systems. J. Dispersion Sci. Technol., 28(8), 1218-1222.

Cross, J. (1998). Anionic surfactants. Analytical chemistry. Surfactant Science Series, Vol. 73, 2nd Ed. New York: Marcel Dekker Inc.

Djedri, S., Issaadi, R., Le Cerf, D., Picton, L. \& MoulaiMostefa, N. (2010). Surfactants synthesis using petroleum fractions and crude oil: Application in microemulsion formulation. J. Dispersion Sci. Technol., 31(7), 877-882.

El-Batanoney, M., Abdel-Moghny, T. \& Ramzi, M. (1999). The effect of mixed surfactants on enhancing oil recovery. J. Surfact. Detergents, 2(2), 201-205.

Gregersen, C. S., Kazempour, M. \& Alvarado, V. (2013). ASP design for the Minnelusa formation under low-salinity conditions: Impacts of anhydrite on ASP performance. Fuel, 105: 368-382.
Harban, A. A. \& Johnson, C. E. (1963). Enciclopedia de tecnología química. 1th ed. México D.F.: UTEHA.

Huh, C. (1979). Interfacial tension and solubilizing ability of a microemulsion phase that coexists with oil and brine. $J$. Colloid Interface Sci., 71(2), 408-428.

Iglauer, S., Wu, Y., Shuler, P., Tang, Y. \& Goddard III,W. A. (2010). New surfactant classes for enhanced oil recovery and their tertiary oil recovery potential. J. Petrol. Sci. Eng., 71(1-2), 23-29.

Jamaloei, B. Y. (2009). Insight into the chemistry of surfactant-based enhanced oil recovery processes. Recent Patents on Chem. Eng., 2(1), 1-10.

Lee, S. \& Puttnam, N. A. (1967). Rapid desulfonation of alkylbenzene sulfonates. J. Am. Oil Chem. Soc., 44(2), 158-159.

Levitt, D., Jackson, A., Heinson, C., Britton, L. N., Malik, T., Dwarakanath, V. \& Pope, G. A. (2009). Identification and evaluation of high-performance EOR surfactants. SPE Reservoir Evaluation \& Engineering, 12(2), 243-253.

Liu, Q., Dong, M., Yue, X. \& Hou, J. (2006). Synergy of alkali and surfactant in emulsification of heavy oil in brine. Colloids Surf. A: Physicochem. Eng. Aspects., 273(1-3), 219-228.

Meléndez, L. V., Lache, A., Orrego-Ruíz, J. A., Pachón, Z. \& Mejía-Ospino, E. (2012). Prediction of the SARA analysis of Colombian crude oils using ATR-FTIR spectroscopy and chemometric methods. J. Petrol. Sci. Eng., 90-91: 56-60.

Melrose, J. C. \& Brandner, C. F. (1974). Role of capillary forces in detennining microscopic displacement efficiency for oil recovery by waterflooding. J. Can. Petrol. Technol., 13(4), 54-59.

Nazar, M. F., Shah, S. S. \& Khosa, M. A. (2011). Microemulsions in enhanced oil recovery: A review. Petrol. Sci. Technol., 29(13), 1353-1365.

Salager, J. L. (1977). Physico-chemical properties of surfactant-water-oils mixtures: Phases behavior, microemulsion formation and interfacial tension. Ph.D. Thesis, Department of Chemical Engineering, University of Texas at Austin, Texas, USA, 256pp. 
Salager, J. L., Anton, R. \& Aubry, J. M. (2006). Formulation des émulsions par la méthode du HLD. Techniques de l’ingénieur. Génie des Procédés J2(158), 1-16.

Salager, J. L., Forgiarini, A. M., Márquez, L., Manchego, L. \& Bullón, J. (2013). How to attain an ultralow interfacial tension and a three-phase behavior with a surfactant formulation for enhanced oil recovery: A review. Part 2. Performance improvement trends from Winsor's premise to currently proposed inter- and intra-molecular mixtures. J. Surf. Deterg., 16(5), 631-663.

Sandvik, E. I., Gale, W. W. \& Denekas, M. O. (1977). Characterization of petroleum sulfonates. SPE Journal, 17(3), 184-192.

Sánchez, J. \& Del Valle, M. (2005). Determination of anionic surfactants employing potentiometric sensors - A review. Crit. Rev. Anal. Chem., 35(1), 15-29.

Sheng, J. J. (2011). Modern chemical enhanced oil recovery. 1 th ed. Burlington: Elsevier.

Taber, J. J. (1969). Dynamic and static forces required to remove a discontinuous oil phase from porous media containing both oil and water. SPE Journal, 9(1), 3-12.

Thanaa, A. M. (2006). Surfactant formulations in enhanced oil recovery. In: Showell, M. Handbook of detergents. Part D. Formulation. Ohio: Taylor and Francis Group, 325-345.

Villalanti, D. C., Raia, J. C. \& Maynard, J. B. (2000). Hightemperature simulated distillation applications in petroleum characterization. In: Meyers, R. A., Encyclopedia of analytical chemistry. Chcichester: John Wiley \& Sons Ltd., 6726-6741.

Wade, W. H., Morgan, J. C., Schechter, R. S., Jacobson, J. K. \& Salager, J. L. (1978). Interfacial tension and phase behavior of surfactant systems. SPE Journal, 18(4), 242-252.

Winsor, P. (1954). Solvent properties of amphiphilic compounds. London: Butterworth.

Witthayapanyanon, A., Harwell, J. H. \& Sabatini, D. A. (2008). Hydrophilic-Lipophilic Deviation (HLD) method for characterizing conventional and extended surfactants. J. Colloid Interf. Sci., 325(1), 259-266.

Wu, Y., Shuler, P. J., Blanco, M., Tang, Y. \& Goddard, W. A. (2005). A study of branched alcohol propoxylate sulfate surfactants for improved oil recovery. SPE Annual
Technical Conference and Exhibition, Dallas, USA. SPE 95404.

Zhang, D, Zhang, P., Zou, H., Chu, G., Wu, W., Zhu, Z., Shao, L. \& Chen, J. (2010). Synthesis of petroleum sulfonate surfactant by different sulfonating agnet with application of HIGEE technology. Chin. J. Chem. Eng., 18(5), 848-855.

\section{AUTHORS}

\section{Zarith del Pilar Pachón-Contreras}

Affiliation: Ecopetrol S.A. - Instituto Colombiano del Petróleo (ICP) Chemist, Universidad Industrial de Santander

M. Sc. in Chemistry, Universidad Industrial de Santander e-mail: zarith.pachon@ecopetrol.com.co

\section{Fernando-Andrés Rojas-Ruíz}

Affiliation: UT Pexlab

Chemist, Universidad Industrial de Santander

M.Sc. in Chemistry, Universidad Industrial de Santander

e-mail: fernandoan.rojas@ecopetrol.com.co

\section{Miguel-José Rondón-Antón}

Affiliation: UT Pexlab

Chemical Engineering, Universidad de los Andes

$\mathrm{Ph}$. D. in Chemical Engineering, Université de Pau et des Pays de l'Adour

e-mail:migueljrondon@gmail.com

\section{Juliana-Carolina Vidal-Prada}

Affiliation: UT Pexlab

Chemical Engineering, Universidad Industrial de Santander M.Sc. in Chemical Engineering in Universidad Industrial de Santander

e-mail: julianavidal33@hotmail.com

Freddy-Alexander Pulido-Solano

Affiliation: UT Pexlab

Chemist, Universidad Industrial de Santander

e-mail: fralpuso@hotmail.com 


\section{NOTATION}

$\sigma \quad$ Characteristic parameter for the surfactant

ln $S \quad$ Natural logarithm of the salinity of the aqueous phase, weight $\%$ of $\mathrm{NaCl}$

EACN Number of carbons of the equivalent alkane to the oil

$\Delta T \quad$ Temperature difference respect to a reference, ${ }^{\circ} \mathrm{C}$

$k$ and $t \quad$ Parameters depending on the type of surfactant employed

A Alcohol percentage eventually added, weight $\%$

$S R_{W} \quad$ Solubilization ratio of water

$S R_{O} \quad$ Solubilization ratio of oil

$V_{W} \quad$ Volume of water dissolved, $\mathrm{mL}$

$V_{O} \quad$ Volume of oil dissolved, $\mathrm{mL}$

$V_{S} \quad$ Volume or surfactant mass in the microemulsion phase, $\mathrm{mL}$ or $\mathrm{g}$ 
